\title{
1 Gender disparities in international COVID-19 clinical trial leadership
}

2

\section{Affiliations:}

1. Division of Infection and Global Health Research, School of Medicine, University of St Andrews, United Kingdom

2. NHS Lothian Infection Service, Regional Infectious Diseases Unit, Western General Hospital,

Edinburgh, United Kingdom

3. Network Science Institute, Northeastern University, Boston, Massachusetts, United States

4. Division of Infectious Diseases, Brigham and Women's Hospital, Boston, Massachusetts, United States

5. Division of Infectious Diseases, Medical University of South Carolina, Charleston, South Carolina,

United States

6. Harvard Medical School, Boston, Massachusetts, United States

7. Boston Children's Hospital, Harvard Medical School, Boston, MA, United States

8. Blizzard Institute, Queen Mary University of London, London, United Kingdom

9. Royal London Hospital, Barts Health NHS Trust, London, United Kingdom

(1)

2

3

\section{Author of correspondence:}

Name: Dr Muge Cevik

Address: Division of Infection and Global Health Research, School of Medicine, University of St Andrews, Fife, KY16 9TF

28 Telephone number: +447732800814

30

Email address: mc349@st-andrews.ac.uk

NOTE: This preprint reports new research that has not been certified by peer review and should not be used to guide clinical practice. 1 
medRxiv preprint doi: https://doi.org/10.1101/2020.08.02.20166751; this version posted August 5, 2020. The copyright holder for this preprint (which was not certified by peer review) is the author/funder, who has granted medRxiv a license to display the preprint in perpetuity. It is made available under a CC-BY-NC 4.0 International license.

\section{Abstract}

32 The COVID-19 pandemic offers considerable possibilities for research and leadership that might equalize

33 opportunity in a new field; however, our study finds instead that more than two-thirds of investigators

34 leading COVID-19-related clinical studies are predicted to be men. These gender disparities in trial

35 leadership during the pandemic suggest that the structural reproduction of inequalities in research has

36 taken place once again in this new academic field. This indicates that policies are needed to facilitate

37 the identification and implementation of strategies to correct gender bias. The active participation of

38 women, trans and gender-nonconforming individuals are needed in research to drive scientific discovery

39 and innovation as well as to better address health disparities.

40

41

42

43

44

45

46

47

48

49

50

51

52

53

54 Key words: COVID-19, coronavirus, pandemic, SARS-CoV-2, novel coronavirus, gender 
medRxiv preprint doi: https://doi.org/10.1101/2020.08.02.20166751; this version posted August 5, 2020. The copyright holder for this preprint (which was not certified by peer review) is the author/funder, who has granted medRxiv a license to display the preprint in perpetuity.

It is made available under a CC-BY-NC 4.0 International license .

\section{Introduction}

57 In addition to the human and financial loss associated with the novel Coronavirus Disease 2019 (COVID-

58 19) pandemic, COVID-19 has also had a significant impact on both the personal and professional life of

59 the global workforce, including that of the scientific research community [1-3]. Before COVID-19,

60 women occupied fewer leadership positions, led a fewer funded studies, and applied for and received

61 less grant funding than men when they did apply [4-7]. The employment gap that occurs when women

62 take parental leave impacts the rate of academic advancement and in turn the receipt of institutional

63 support to apply for and secure funding $[6,7]$. These imbalances contribute to systemic inequalities that

64 hamper women's access to and progress in science $[2,7,8]$. A review of the gender distribution of 24

65 COVID-19 national task forces suggests that many committees are comprised of less than a quarter

66 women, indicating that women's voices and expertise have been excluded from decision making during

67 this unprecedented public health emergency [9].

68

69 For example, emerging data suggest that across all disciplines, despite an increased number of peer-

70 reviewed articles submitted to journals during the pandemic, women have published fewer papers than

71 men thus far this year [10]. This may indicate a similarly reduced involvement of women in research

72 leadership positions and an imbalanced distribution of grants and funding -- important indicators of

73 advancement in a scientist's academic career [4-7, 10, 11]. Being principal investigator (PI) on a clinical

74 trial is strongly associated with advancement to full professor among women academics in infectious

75 diseases [8].

76

77 The COVID-19 pandemic offers numerous opportunities in clinical research. These include trials to assess

78 the safety and efficacy of medical interventions, with protocols in various stages of implementation. 
medRxiv preprint doi: https://doi.org/10.1101/2020.08.02.20166751; this version posted August 5, 2020. The copyright holder for this preprint (which was not certified by peer review) is the author/funder, who has granted medRxiv a license to display the preprint in perpetuity.

It is made available under a CC-BY-NC 4.0 International license.

79 Here, we provide a timely analysis to compare the gender distribution of clinical trial leadership in

80 COVID-19 clinical trials.

81

82 Materials and Methods

83 We systematically searched https://clinicaltrials.gov/ and retrieved all clinical trials on COVID-19

84 registered from January 1, 2020 to June 26, 2020 using “COVID” as a keyword. As a comparator group,

85 we have chosen two fields that are not related to emerging infections: breast cancer and type 2 diabetes

86 mellitus (T2DM). We retrieved all clinical trials related to these comparator conditions registered at

87 https://clinicaltrials.gov/ within the aforementioned study period as well as those registered in the

88 preceding year (pre-study period: January 1, 2019 and December 31, 2019). Gender of the investigator

89 was predicted using the genderize.io API (application programming interface). This tool has been used to

90 predict the gender of first names in studies regarding gender bias $[12,13]$ and achieves a minimum

91 accuracy of $82 \%$, with an F1 score of $90 \%$ for women and $86 \%$ for men [14]. Clinical trials were excluded

92 if i) investigator information was not provided; ii) the genderize.io API could not predict any of the

93 investigators' gender from their first name; or iii) organization or company names were provided as the

94 investigator. The number of studies that were excluded for the above reasons are reported in the

95 supplementary flow diagram. An exploratory temporal analysis was conducted with the available data.

96 Categorical variables were summarized by frequencies and percentages. We compared groups using Chi-

97 square testing for equality of proportions with continuity correction.[15] The analysis was performed

98 using $\mathrm{R}$ (Version 4.0.2). The repository of the datasets used to collect and analyse the data available at

99 https://osf.io/k2r57/.

100

101 Results 
medRxiv preprint doi: https://doi.org/10.1101/2020.08.02.20166751; this version posted August 5, 2020. The copyright holder for this preprint (which was not certified by peer review) is the author/funder, who has granted medRxiv a license to display the preprint in perpetuity.

It is made available under a CC-BY-NC 4.0 International license.

102 We identified 2345 COVID-19-related clinical trials. Of those, 1448 had at least one investigator (i.e.,

103 principal investigator, study director, or study chair) identified whose gender could be predicted. In the

104 comparator group, we identified 449 trials on breast cancer and 272 on T2DM that were registered. Of

105 those, 274 breast cancer studies and 139 T2DM studies had at least one investigator whose gender

106 could be predicted.

107

108 Overall $27.8 \%$ of PIs among COVID-19-related studies were predicted to be women, which is significantly

109 different compared to $54.4 \%$ and $42.1 \%$ for breast cancer $(p<0.005)$ and T2DM $(p<0.005)$ trials over the

110 same period, respectively (Table 1). While there has been a small increase in the proportion of Pls who

111 were predicted to be women in May 2020, clinical research leadership for COVID-19 among this group

112 was below 25\% for the remainder of the study period (Supplementary Material). While $31.4 \%$ of study

113 chairs were predicted to be women in COVID-19-related studies, 32.1\% ( $p=0.7)$ and $63.6 \%(p<0.01)$ were

114 predicted to be women in breast cancer and T2DM trials, respectively. Proportion of study chairs were

115 not significantly different across the three fields.

116

117 We also reviewed comparator group studies registered before January 1, 2020 to determine whether

118 the pandemic might have affected gender distribution of trial leadership. We identified 839 clinical trials

119 related to breast cancer and 533 on T2DM over a 12-month period prior to January 1,2020 . Of those,

120573 breast cancer studies and 359 T2DM studies yielded at least one investigator whose gender could

121 be predicted. During this "pre-study" period, the proportion of PIs who were predicted to be women

122 were $49.7 \%$ and $44.4 \%$ for breast cancer and T2DM trials, respectively and the difference was not

123 statistically significant when compared to results from the study period ( $p>0.05)$.

125 Discussion 
medRxiv preprint doi: https://doi.org/10.1101/2020.08.02.20166751; this version posted August 5, 2020. The copyright holder for this preprint (which was not certified by peer review) is the author/funder, who has granted medRxiv a license to display the preprint in perpetuity.

It is made available under a CC-BY-NC 4.0 International license.

126 In this study, we demonstrate that less than one-third of COVID-19-related clinical trials are led by PIs

127 who were predicted to be women, half the proportion observed in non-COVID-19 (breast cancer and

128 T2DM) trials over the same period. The proportion of PIs in breast cancer and T2DM studies also

129 remained similar to the pre-study period. These gender disparities during the pandemic may indicate

130 not only a lack of women's leadership in international clinical trials and involvement in new projects, but

131 also may reveal imbalances in women's access to research activities and funding during health

132 emergencies $[2,16]$.

133

134 The COVID-19 pandemic offers numerous opportunities for research and leadership that could equalize

135 opportunity in a new field, but our results suggest the opposite. The pandemic has reinforced the

136 prevailing gender norms in which men continue to be allocated a disproportionate share of the funding,

137 as well as leadership and authorship roles $[9,10,16]$. One potential contributor for this discrepancy is

138 the speed demanded by the research agenda during the pandemic. The sense of urgency in starting

139 clinical trials may lead to an abandonment of any checks and balances around equality and inclusion

140 that would have otherwise encouraged the involvement of women scientists. Many women scientists

141 have already raised concerns about institutional funding distribution lacking gender balance or being left

142 out of research activities despite their expertise $[2,16]$. During COVID-19 pandemic, a UK study showed

143 that women were more than twice as likely to take on childcare and schooling responsibilities of

144 children than men, while male academic counterparts leverage professional relationships and networks

145 more effectively $[1,2,16]$.

147 As a community, we must recognise that there is a tendency to "turn to men" in times of crisis both for

148 leadership and scientific expertise $[2,3,16,17]$, highlighting the need to challenge this culture. Research

149 and academia are already competitive; being in the central decision-making group is often challenging 
medRxiv preprint doi: https://doi.org/10.1101/2020.08.02.20166751; this version posted August 5, 2020. The copyright holder for this preprint (which was not certified by peer review) is the author/funder, who has granted medRxiv a license to display the preprint in perpetuity.

It is made available under a CC-BY-NC 4.0 International license .

150 due to gender norms, along with roles and rules on how these groups are established and maintained;

151 during health emergencies, these same authoritative circles become more difficult for women scientists

152 to join $[2,16]$. Our findings suggest that there is a need for transparency in opportunities and funding

153 that requires actively identifying and addressing the structurally implicit and unconscious biases that

154 favour men.

155

156 Our analysis has some limitations. We could include only 50-75\% of trials for which an investigator's

157 gender could be algorithmically predicted. Furthermore, while such algorithms allow for the rapid

158 analysis of gender disparities such as those conducted here, they can also be exclusionary to gender

159 non-conforming, non-binary, and trans individuals. Because of this, we have taken care to use the term

160 "predicted gender" throughout the text whenever discussing algorithm-based gender assignment in

161 acknowledgement of gender non-conforming, non-binary, and trans investigators. Beyond these

162 limitations, we did not consider studies that received private funding, which may not have been

163 registered on clinicaltrials.gov; however, it is worth noting that clinicaltrials.gov is an international

164 database with widespread international representation.

165

166 In summary, while the COVID-19 pandemic has thus far provided many new opportunities for research,

167 with numerous clinical trials initiated worldwide, a disproportionate proportion of PIs leading COVID-19

168 related studies are predicted to be men, despite women accounting for $70 \%$ of the global health

169 workforce [16]. Our demonstration of gender differences in trial leadership and grant allocation argue

170 for revised policies and strategies that encourage the participation of women in pandemic research. Not

171 only can these women drive discovery and innovation, but they can act to address health disparities and

172 provide role models for the next generation of women scientists $[2,16,18,19]$. Ensuring gender

173 representation would also reflect the commitment of the global community to promoting gender 
medRxiv preprint doi: https://doi.org/10.1101/2020.08.02.20166751; this version posted August 5, 2020. The copyright holder for this preprint (which was not certified by peer review) is the author/funder, who has granted medRxiv a license to display the preprint in perpetuity.

It is made available under a CC-BY-NC 4.0 International license .

174 equality in academic medicine and research: inclusion, diversity, representation, progression, and

175 success for all. A health emergency is not an excuse for disregarding the importance of equitable

176 representation and given the disproportionate burden of such outbreaks for communities who are

177 marginalized due to their gender, sexuality, class, ethnicity, and ability an even greater reason we must

178 advocate for it [20-22].

179

180

181

182

183 Authors contributions

184 MC: conceptualisation, methodology, investigation, literature review, data curation, writing - original

185 draft. SH and MM: investigation, data curation, formal analysis, writing - review and editing; JS, KK, PS:

186 methodology, writing - review and editing, supervision. CO: conceptualisation, methodology,

187 investigation, literature review, writing - original draft, supervision.

188

189 Financial support and sponsorship

190 None

191

\section{Conflict of interests}

$193 \mathrm{MC}, \mathrm{SH}, \mathrm{JS}, \mathrm{KK}, \mathrm{MM}$ have none to disclose. CO has received honoraria, fees for lectures, and advisory

194 boards from Gilead, MSD, Viiv, and Janssen. She has also received research grants to her institution from

195 the above-mentioned companies. PES has received honoraria, fees for lectures, and advisory boards

196 from Gilead, Merck, Janssen, and ViiV; he has also received research grants to his institution from Gilead

197 and ViiV. 
medRxiv preprint doi: https://doi.org/10.1101/2020.08.02.20166751; this version posted August 5, 2020. The copyright holder for this preprint (which was not certified by peer review) is the author/funder, who has granted medRxiv a license to display the preprint in perpetuity.

It is made available under a CC-BY-NC 4.0 International license .

\begin{tabular}{|c|c|c|c|c|c|c|c|c|}
\hline & \multicolumn{5}{|c|}{ Jan 1, 2020 - June 26, 2020} & \multicolumn{3}{|c|}{ before Jan 1, 2020} \\
\hline & $\begin{array}{r}\text { COVID } \\
-19\end{array}$ & $\begin{array}{l}\text { Breast } \\
\text { Cancer }\end{array}$ & p value & T2DM & $p$ value & $\begin{array}{l}\text { Breast } \\
\text { Cancer }\end{array}$ & T2DM & p value \\
\hline $\mathbf{P I}$ & $27.8 \%$ & $54.4 \%$ & $<0.001$ & $42.1 \%$ & $<0.001$ & $49.7 \%$ & $44.4 \%$ & 0.158 \\
\hline $\begin{array}{l}\text { Study } \\
\text { Director }\end{array}$ & $28.7 \%$ & $48.9 \%$ & 0.0103 & $22.2 \%$ & 0.751 & $30.5 \%$ & $47.6 \%$ & 0.028 \\
\hline $\begin{array}{l}\text { Study } \\
\text { Chair }\end{array}$ & $31.4 \%$ & $32.1 \%$ & 1 & $36.36 \%$ & 0.98 & $33.3 \%$ & $40.4 \%$ & 0.54 \\
\hline
\end{tabular}

\section{Supplementary material:}

204 Flow diagram of process of selection

205 Gender distribution over time (months)

\section{References:}

1. Villadsen A, Conti, G. and Fitzsimons, E. Parental involvement in home schooling and developmental play during lockdown - Initial findings from the COVID-19 Survey in Five National Longitudinal Studies. . London: UCL Centre for Longitudinal Studies. 2020. 2. Education TH. Women in science are battling both Covid-19 and the patriarchy 2020 [cited 2020 June 6]. Available from: https://www.timeshighereducation.com/blog/womenscience-are-battling-both-covid-19-and-patriarchy\#survey-answer.

2153 3rubaker L. Women Physicians and the COVID-19 Pandemic. JAMA. 2020. doi:

216 10.1001/jama.2020.14797.

217 4. Head MG, Fitchett JR, Cooke MK, Wurie FB, Atun R. Sex discrepancies in infectious

218 disease research funding 1997\&\#x2013;2010: a systematic analysis. The Lancet. 2013;382:S44. 219 doi: 10.1016/S0140-6736(13)62469-1.

220 5. Hoa NT, Thuong NTT, Clapham HE, Thu TTA, Kestelyn E, Thwaites CL. Increasing women's leadership in science in Ho Chi Minh City. The Lancet. 2019;393(10171):523-4. doi:

223 6. Blake M LVI. Who Applies for Research Funding? 
medRxiv preprint doi: https://doi.org/10.1101/2020.08.02.20166751; this version posted August 5, 2020. The copyright holder for this preprint (which was not certified by peer review) is the author/funder, who has granted medRxiv a license to display the preprint in perpetuity.

It is made available under a CC-BY-NC 4.0 International license .

224 7. Jefferson L, Bloor K, Maynard A. Women in medicine: historical perspectives and recent trends. British Medical Bulletin. 2015;114(1):5-15. doi: 10.1093/bmb/ldv007.

8. Manne-Goehler J, Kapoor N, Blumenthal DM, Stead W. Sex Differences in Achievement and Faculty Rank in Academic Infectious Diseases. Clinical Infectious Diseases. 2019;70(2):290-6. doi: 10.1093/cid/ciz200. Covid-19 response: a call for more inclusive and transparent decision-making. BMJ Global Health. 2020;5(5):e002655. doi: 10.1136/bmjgh-2020-002655. 10. Andersen JP, Nielsen MW, Simone NL, Lewiss RE, Jagsi R. COVID-19 medical papers have fewer women first authors than expected. eLife. 2020;9:e58807. doi: 10.7554/eLife.58807. 11. D'Armiento J, Witte SS, Dutt K, Wall M, McAllister G. Achieving women's equity in academic medicine: challenging the standards. The Lancet. 2019;393(10171):e15-e6. doi: 10.1016/S0140-6736(19)30234-X.

12. Holman L, Stuart-Fox D, Hauser CE. The gender gap in science: How long until women are equally represented? PLoS Biol. 2018;16(4):e2004956. Epub 2018/04/20. doi: 10.1371/journal.pbio.2004956. PubMed PMID: 29672508; PubMed Central PMCID: PMCPMC5908072.

13. Huang J, Gates AJ, Sinatra R, Barabasi AL. Historical comparison of gender inequality in scientific careers across countries and disciplines. Proc Natl Acad Sci U S A. 2020;117(9):460916. Epub 2020/02/20. doi: 10.1073/pnas.1914221117. PubMed PMID: 32071248; PubMed Central PMCID: PMCPMC7060730.

14. Karimi F WC, Lemmerich F, Jadidi M, Strohmaier M. . Inferring gender from names on the web: a comparative evaluation of gender detection meth- ods. Proceedings of the 25th international conference companion on world wide web, WWW'16 companion. 2016.

15. Newcombe RG. Interval estimation for the difference between independent proportions: comparison of eleven methods. Stat Med. 1998;17(8):873-90. Epub 1998/05/22. doi: 10.1002/(sici)1097-0258(19980430)17:8<873::aid-sim779>3.0.co;2-i. PubMed PMID: 9595617. 16. Gabster BP, van Daalen K, Dhatt R, Barry M. Challenges for the female academic during the COVID-19 pandemic. Lancet. 2020;395(10242):1968-70. Epub 2020/06/22. doi: 10.1016/S0140-6736(20)31412-4. PubMed PMID: 32563275; PubMed Central PMCID: PMCPMC7302767.

255 17. WEP. Women Expert Project 2020. Available from: https://expertwomenproject.com. discovery and innovation. Nature Human Behaviour. 2018;2(10):726-34. doi: 10.1038/s41562018-0433-1.

19. A call for more inclusive Covid-19 research: Tackling disparities during a pandemic 2020. Available from: https://www.statnews.com/sponsor/2020/05/22/a-call-for-more-inclusivecovid-19-research-tackling-disparities-during-a-pandemic/.

20. Koma W, Artiga, S., Neuman, T., Claxton, G.,Rae,M.,Kates,J.,Michaud, J. . Low-Income and Communities of Color at Higher Risk of Serious Illness if Infected with Coronavirus 2020 [cited 2020 July 21]. Available from: https://www.kff.org/coronavirus-covid-19/issuebrief/low-income-and-communities-of-color-at-higher-risk-of-serious-illness-if-infected-withcoronavirus/.

21. Finch WH, Hernández Finch ME. Poverty and Covid-19: Rates of Incidence and Deaths in the United States During the First 10 Weeks of the Pandemic. Frontiers in Sociology.

269 2020;5(47). doi: 10.3389/fsoc.2020.00047. 
medRxiv preprint doi: https://doi.org/10.1101/2020.08.02.20166751; this version posted August 5, 2020. The copyright holder for this preprint (which was not certified by peer review) is the author/funder, who has granted medRxiv a license to display the preprint in perpetuity.

It is made available under a CC-BY-NC 4.0 International license .

$27022 . \quad$ Chen J, Krieger, N. Revealing the unequal burden of COVID-19 by income, 271 race/ethnicity, and household crowding: US county vs. ZIP code analyses: Harvard Center for 272 Population and Development Studies; 2020 [cited 2020 July 26]. Available from:

273 https://cdn1.sph.harvard.edu/wp-content/uploads/sites/1266/2020/04/HCPDS_Volume-

274 19_No_1_20_covid19_RevealingUnequalBurden_HCPDSWorkingPaper_04212020-1.pdf.

275 